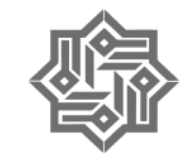

KALAM, p-ISSN: 0853-9510 e-ISSN: 2540-7759

http://ejournal.radenintan.ac.id/index.php/KALAM

Volume 10, No. 2, Desember 2016, halaman 381 - 402

\title{
Islam Toleran: \\ Membangun Toleransi dengan Jalan Spiritual
}

\author{
Andi Eka Putra \\ IAIN Raden Intan Lampung \\ andieka@yahoo.com
}

\begin{abstract}
Abstrak
Banyak jalan yang pernab dicoba dan ditempub dalam rangka membangun Islam toleran di Indonesia. Berbagai jalan yang pernah dicoba itu adalah jalan dialog dengan berbagai modelnya, komunikasi etnik, kerukunan umat beragama, hingga kerjasama. Secara teoritik, beberapa pendekatan pernah ditempuh dan dijalankan dalam rangka membangun toleransi yang sunggub-sungguh. Salah satu pendekatan teoritik yang cukup signifikan dan kontekstual dalam membangun Islam toleran di Indonesia adalah melalui pendekatan tasawuf atau jalan spiritual Islam. Ekspresi spiritual lebih mengedepankan keharmonisan, keterbukaan dan penerimaan akan yang lain yang sejati, tanpa basa-basi atau toleransi yang semu. Spiritualitas adalah inti keberagamaan di Indonesia yang dapat ditawarkan kepada dunia.
\end{abstract}

\begin{abstract}
Many roads have been tried and adopted in order to build a Islam tolerant in Indonesia. Various road ever attempted it is the path of dialogue with the various models, communication ethnic, religious barmony, and cooperation. Theoretically, several approaches have ever taken and implemented in order to build tolerance earnest. One significant theoretical approach and contextual in building a tolerant Islam in Indonesia is through the approach of Sufism or Islamic spiritual path. More mengedepankankeharmonisan spiritual expression, openness
\end{abstract}


and acceptance of others which is true, without preamble or false tolerance. Spirituality is the core of diversity in Indonesia that can be offered to the world.

Keyword: Islam, toleransi, spiritual.

\section{A. Latar Belakang Masalah}

Kemajemukan agama dan sosial-budaya akan tetap merupakan gejala menonjol dan amat penting di Indonesia, yang selalu diperhitungkan dalam merumuskan berbagai kebijakan. Kondisi sosial dan budaya yang majemuk memerlukan adanya sebuah titik temu dalam nilai kesamaan dari semua kelompok yang ada. Salah satu titik temu dalam nilai kesamaan dari kelompok budaya yang berbeda-beda adalah dengan bersikap toleran. Toleransi inilah dasar penopang bagi berdirinya sebuah negara besar yang plural yang bernama Indonesia.

Meneguhkan semangat toleransi berarti menjunjung tinggi keanekaragaman. Termasuk keanekaragaman ekspresi keagamaan, keanekaragaman aliran dan kepercayaan. Inilah kenyataan historis yang tak terelakkan, bukan suatu kehendak atau rekayasa manusia. Kemajemukan adalah kenyataan yang mesti diterima dengan lapang dada. Sebab dengan menerimanya sebagai kenyataan hidup, maka akan mengantarkan seseorang pada sikap historis yang dilandasi oleh sikap kedewasaan. Ini penting mengingat di hari-hari belakangan ini bangsa ini masih tetap berada dalam jalur kebhinekaan yang telah menjadi kenyataan sejarah sejak Republik Indonesia menyatakan kemerdekaan lebih dari tujuh puluh tahun lalu.

Namun, persoalan toleransi dengan segala variannya di negeri ini seperti tak habis-habisnya dipersoalkan sejak republik ini merdeka. Kata ini kian lama kian kehilangan pesona karena begitu sering dibicarakan. Toleransi jauh lebih sering diucapkan, didiskusikan, diperdebatkan, diseminarkan, bahkan dijadikan pilot proyek hampir setiap pergantian pemerintahan di Indonesia. Tetapi, implementasinya masih tersendat-sendat, dan tak jarang berhenti pada tataran kata-kata.

Diskursus tentang toleransi telah menyita perhatian banyak kalangan, mulai dari pemerintah pusat hingga daerah, kalangan 
perguruan tinggi, agamawan, budayawan, seniman, aktivis lembaga swadaya masyarakat, hingga mahasiswa.

Membicarakan toleransi tanpa menghubungkannya dengan Islam serasa tidak sah dan kurang sahih. Maka pembicaraan tentang Islam dan toleransi pun menjadi trend tersendiri di kalangan para dosen dan mahasiswa, di samping pemerintah. Sejak Menteri Agama dijabat oleh A. Mukti Ali, masalah Islam dan toleransi sudah sangat sering diseminarkan dan terus didiskusikan hingga hari ini. Proyek kerukunan antar umat beragama serta dibukanya jurusan Perbandingan Agama di IAIN merupakan jasa terbesar mendiang A. Mukti Ali, dan terus dirawat oleh Alamsyah Prawiranegara, Munawir Sadjali, dan lain-lain.

Ambil contoh kebijakan Alamsyah Perwiranegara. Semasa menjabat Menteri Agama, Alamsyah dikenal dengan konsep Tri Kerukunan Umat Beragama, yaitu: (1) kerukunan antar umat beragama, (2) kerukunan intern umat beragama, (3) kerukunan antar umat beragama dengan pemerintah. ${ }^{1}$ Melalui konsep kerukunan umat beragama ini diharapkan tumbuhnya sikap toleran dan terbuka sebagai prasyarat berlangsungnya proses pembangunan bangsa yang berkeadaban di Indonesia.

Klaim bahwa Islam adalah agama toleran, tentu saja bukan sekedar apologi dan pembelaan diri. Sejarah Islam sendiri telah bersinggungan dengan sangat rapat terhadap masalah toleransi, terutama ketika pada masa Rasulullah hijrah ke Madinah. Toleransi menjadi jalan keluar dalam menyikapi berbagai kepercayaan dan agama. Sebagian pengamat berpendapat bahwa Islam adalah agama yang menghargai pluralitas ekspresi keagamaan. Islam bukan agama teror atau agama kekerasan. Banyak bukti menunjukkan bahwa umat Islam dapat hidup berdampingan secara damai dengan komunitas agama lain di berbagai belahan dunia. Umat Islam juga tidak menutup kemungkinan adanya penafsiran dari kalangan Islam yang tertutup, yang keras dan intoleran sejak masa klasik hingga sekarang.

Beberapa tahun terakhir cukup beragam tantangan bagi mereka yang consern mengenalkan wajah Islam yang ramah dan

1Lihat Nur Syam, Tantangan Multikulturalisme Indonesia: Dari Radikalisme Menuju Kebangsaan, (Yogyakarta: Kanisius, 2009), h. 54. 
toleran. Munculnya berbagai aliran Islam mancanegara di negeri ini, sepeti Hizbu Tahrir, Ikhwan Al-Muslimin, Hizbullah, Salafi, dan lain sebagainya, kian menambah ruwet relasi anta rumat beragama. Sebagian besar aliran yang eksklusif dan menekankan kehendaknya di negeri ini kerapkali berbenturan dengan kalangan yang lebih inklusif dan yang menerima toleransi sebagai syarat mutlak hidup di negara majemuk seperti Indonesia.

Siapa pun tak dapat memaksakan kepercayaannya kepada pihak lain, apalagi dengan jalan teror dan kekerasan. Maka toleransi adalah pilihan sikap hidup beragama di tengah keanekaragaman kepercayaan dan aliran. Toleransi sama sekali tidak menekankan kehendak menyamakan semua kepercayaan, karena hal itu tidak mungkin dan betentangan dengan kenyataan sejarah. Toleransi merupakan sikap kedewasaan dalam menerima dan mengelola berbagai aliran. Sebuah sikap persaudaraan yang dilandasi ajaran agama.

Inilah pilihan yang untuk sebagian orang dianggap masih sangat sulit diterima dan dijalankan. Bersikap toleran dengan adanya agama dan kepercayaan lain tidak berarti secara telogis, mengimani agama dan kepercayaan lain. Sebab ini mustahil di jalankan dan dilakukan.

Jika mengikuti perkembangan akhir-akhir ini, tampaknya telah terjadi defisit hubungan antar umat beragama di Indonesia. Di tingkat nasional, muncul beberapa konflik karena perbedaan paham. Belakangan lahir fatwa MUI tahun 2005 yang mengharamkan sekularisme, liberalisme, dan pluralisme di bumi Indonesia.

Menurut Budhy Munawar-Rachman, fatwa MUI tersebut telah memporak-porandakan begitu banyak kajian dan pemikiran di seputar toleransi, yang selama ini memperbolehkan pluralisme di Indonesia. Fatwa MUI juga melanggar asas-asas dan basis moral keislaman universal, karena fatwa MUI ini sangat eksklusif, intoleran, bahkan cenderung diskriminatif. 2

Di tingkat internasional, Islam terlanjur dipahami sebagai agama intoleran. Petanyaan yang sering muncul di kalangan

2 Budhy Munawar Rachman, Sekularisme, Liberalisme dan Pluralisme, (Jakarta: Grasindo, 2010), h. 7 . 
mahasiswa Barat setelah peristiwa serangan teroris atas menara kembar kebanggaan masyarakat AS pada 11 September 2011 adalah: adakah ajaran toleransi dalam Islam? Bukankah Islam itu agama yang menyebarkan kekerasan dan permusuhan tehadap kaum kafir yang dianggap tidak seiman dengan mereka? ${ }^{3}$

Peristiwa 11 September itu memang menjadi tantangan besar bagi umat Islam agar Islam tidak terus-menerus disalah pahami. Kebanyakan para penulis Barat menempatkan Islam dengan citra yang amat buruk di media massa Barat, yakni Islam sebagai teroris dan tidak toleran. Banyak orang kembali meragukan jika Islam memiliki konsep mengenai hidup bersama yang toleran karena terbukti bahwa kaum muslim menyukai kekerasan. Para penulis Barat pun meragukan jika Islam memiliki konsep kehidupan bersama yang harmonis dalam situasi yang pluralis. Islam digambarkan sebagai agama teror, tertutup, dan tidak toleran.

Tidak kurang dari Wakil Presiden Amerika Serikat merespon peristiw 11 September 2001 itu dengan terang-terangan menunjuk Islam sebagai musuh AS. Sehari setelah peristiwa tersebut ia mengakui bahwa: "Sebelum peristiwa 11 September 2001 yang mengancurkan gedung kembar kebanggaan warga Amerika Serikat, yang menelan korban nyawa 3000 orang, aku bingung siapa musuh besar Amerika Serikat sekarang. Sebab, musuh besar Amerika Serikat telah hilang mendadak setelah Uni Soviet ambruk tahun 1989. Tapi peristiwa 11 September, musuh Amerika Serikat semakin jelas dan tampak, yakni Islam". ${ }^{4}$

Gambara miris di atas juga dilihat oleh dua orang peneliti Barat tentang Islam yang selama ini dikenal sangat empatik dan simpatik terhadap Islam, yakni Karen Amstrong dan John L. Esposito. Dalam buku baru John L. Esposito, Masa Depan Islam, Karen Amstrong menulis dalam kata pengantar begini:

Buku ini penting. Kami yang sejak peristiwa 11 September 2001 berada di garda depan dalam upaya menjelaskan Islam

3 John L. Esposito, Masa Depan Islam: Antara Tantangan Kemajemukan dan Benturan dengan Barat, terj. Yuliani Liputo (Bandung: Mizan, 2010), h. 8.

4Dikutip dari esai Catatan Pinggir Goenawan Mohamad, "11/9", Majalah Tempo Edisi 06 Oktober 2001. Korban serangan teroris atas gedung pentagon di Manhattan sebanyak 3000 orang yang meninggal itu juga dikutip dari tulisan yang sama. 
kepada dunia Barat, segera menyadari bahwa tugas tersebut tidaklah mudah. Selain karena meluasnya ketidaktahuan tentang agama Islam di Eropa maupun di Amerika Serikat, hal itu juga disebabkan keengganan yang sudah berurat berakar untuk melihat Islam dari sudut pandang yang lebih baik tidak jarang terlihat orang menolak keras dan samarsamar memberontak ketika, misalnya, disebutkan bahwa Islam adalah agama toleran dan menjunjung tinggi pluralisme. ${ }^{5}$

Kesaksian John L. Esposito sendiri juga memperkuat betapa pandangan orang Barat terhadap Islam betul-betul miris dan menyedihkan. Islam kerapkali digambarkan tak toleran, tak memiliki tokoh-tokoh pembaru seperti dalam Kristen serta ditempatkan sebagai agama anti-persaudaraan. Tapi sejak pergantian presiden Amerika Serikat yang baru, ada harapan di mana Islam mulai diakui sebagai agama yang memperjuangkan pluralisme. Hal ini dinyatakan sendiri oleh Presiden Barack Obama bahwa: "Islam telah menunjukkan lewat kata-kata dan perbuatan tentang peluang toleransi beragama dan kesetaraan ras...Kemitraan antara Amerika dengan Islam harus didasarkan pada Islam sesungguhnya, bukan pada apa yang bukan Islam". ${ }^{6}$

Sebetulnya, jauh sebelum peristiwa 11 September tersebut, Robert N. Bellah—sosiolog Amerika Serikat—-telah menegaskan bahwa Islam awal di bawah kepemimpinan Nabi Muhammad menunjukkan bahwa, masyarakat Islam-Arab telah membuat satu langkah maju memasuki abad modern, bahkan sangat modern untuk zamannya, di mana kepemimpinan Nabi Muhammad berhasil merangkul dan mengajak komunitas non Islam untuk hidup berdampingan secara damai. Ini artinya, konsep pluralisme dalam Islam telah tertanam sejak lama, sejak Islam awal sekali, yakni Islam di zaman Nabi Muhammad. ${ }^{7}$

5 Karen Amstrong, "Kata Pengantar" buku John L. Esposito, Masa Depan Islam: Antara Tantangan Kemajemukan dan Benturan dengan Barat, terj. Yuliani Liputo (Bandung: Mizan, 2010), h. 11.

${ }^{6}$ Ibid., h. 31.

${ }^{7}$ Robert N. Bellah, Beyond Belief: Esai-esai tentang Agama di Dunia Modern, terj. Rudy Harisyah Alam (Jakarta: Paramadina, 2000), h. 211. 
Ekses dan dampak dari pemberitaan media Barat terhadap Islam di dunia internasional saat ini, juga berpengaruh di Indonesia. Banyak umat Islam memprotes tudingan Barat yang salah kaprah tentang Islam. Di kalangan akademisi muncul sejumlah gagasan untuk mengingatkan kembali nilai-nilai Islam tentang toleransi dan pluralisme, dengan menggali berbagai sumber primer dalam Kitab Suci maupun realitas kehidupan umat islam di Indonesia.

Maka, ketika di hari-hari ini masalah Islam dan toleransi kembali mengemuka, pertanyaan yang segera menyergap penulis adalah: Apalagi yang mesti dibicarakan dan diangkat mengenai Islam dan toleransi di Indonesia? Bukankah sudah begitu banyak pihak menulis dan membukukan masalah ini? Apalagi yang luput dan kurang dari perhatian?

\section{B. Islam dan Dialog Toleransi}

Istilah dialog sudah umum digunakan dalam berbagai literatur tentang hubungan antar agama. Dialog dapat dipahami sebagai suatu perjumpaan dan komunikasi dua arah yang mengandaikan satu sama lain dalam posisi yang setara dan sederajat. Menurut JB. Banawiratma dan Zainal Abidin Bagir, dialog dimulai saat orang-orang bertemu. Dialog bergantung pada pengertian timbal balik dan kepercayaan timbal-balik. Melalui dialoglah dimungkinkan berbagi dalam melayani. Dialog menjadi medium untuk kesaksian yang otentik. ${ }^{8}$

Dengan perkataan lain, sebuah dialog yang baik akan tercapai jika kedua pembicara berada dalam posisi yang seimbang. Pengertian dialog di sini mengacu pada komunikasi antar dua orang atau lebih yang membicarakan suatu pokok persoalan dengan siakp saling menghargai satu sam lain. Di sini dialog dipahami dalam makna yang seluas-luasnya agar dapat menampung sebanyak mungkin potensi yang ada untuk dikembangkan. Ketika orang berbeda agama saling bertemu dan menyapa, di situ terjadi dialog antar umat beragama. Apa pun isi yang dikomunikasikan, dialog terjadi. ${ }^{9}$

8 JB. Banawiratma dan Zainal Abidin Bagir (ed), Dialog Antar umat Beragama: Gagasan dan Pralktik di Indonesia, (Bandung: Mizan, 2010), h. 7.

${ }^{9}$ Nurcholish Madjid, Dialog Keterbukaan (Jakarta: Paramadina, 1998), h. 4 
Di tengah masyarakat yang pluralis, pendekatan dialog amat penting dalam rangka membangun komunikasi yang sehat. Prasyarat dialog semstinya dimulai dengan pemahaman terusmenerus perihal pluralisme sebagai basis dan titik-tolak berbangsa dan bernegara yang toleran. Sebab, sebagaimana dikatakan Budhy Munawar-Rachman, pluralisme di samping mengakui perbedaan juga menganjurkan dialog yang dialogis. Dalam proses dialog tersebut semua saling memahami dan mengapresiasi. ${ }^{10}$

Masalah pendekatan dialog antar agama, dalam sejarah, sebenarnya bukanlah hal yang baru bagi Islam. Sejak awal kemunculannya, umat Islam sudah terbiasa berdialog dengan siapa saja. Di Makkah, sebelum hijrah, Rasulullah dan para sahabat sudah berdialog dengan kaum musyrik Arab dan pengikut Kristen. Saat hijrah ke Habasyah, Ja'far bin Abdul Muthalib sudah berdialog dengan pengikut Kristen dan juga Raja Najasyi yang ketika itu masih memeluk agama Kristen. Di Madinah, Rasulullah SAW melayani perdebatan dengan delegasi Kristen Najran. ${ }^{11}$

Meskipun sejak Nabi dialog sudah dilakukan dan masih terus dilakukan sampai sekarang, namun konflik masih sering terjadi di berbagai belahan dunia, termasuk di Indonesia. Mengapa ini semua bisa terjadi? Ada dua faktor penyebab utama, yaitu faktor eksoterik dan esoterik.

Faktor eksoterik itu meliputi faktor sejarah (historisitas), beban sejarah konflik abad pertengahan, juga faktor sosial dan budaya (kultural). Sedangkan faktor esoterik meliputi lima konsep atau bisa dikatakan dogma, yaitu konsep Ketuhanan (theisme), keselamatan (soteriologi), pemahaman tentang kitab suci (scriptural), klaim kebenaran (truth claims), dan pemahaman tentang agama lain (religiusitas). Dialog teologis yang dimaksudkan di sini adalah dialog yang mencakup kedua wilayah agama tersebut, yaitu eksoterik dan esoterik. ${ }^{12}$

Dalam konteks itu, dapatlah dipahami jika ada anggapan bahwa agama Islam menekankan hidup berdampingan dalam

${ }^{10}$ Budhy Munawar-Rachman, Sekularisme, Liberalisme..., h. 152

${ }^{11}$ Ibid., h. 7

12 Alwi Shihab, Membedah Islam di Barat: Menepis Tudingan, Meluruskan Kesalahpahaman, (Jakarta: PT. Gramedia Pustaka Utama, 2004), h. 42. 
perbedaan dengan cara saling menghargai, menghormati dan toleransi. Pandangan Islam yang terkait dengan toleransi dan kebebasan menganut agama didasarkan kepada al-Qur'an surat alBaqarah: 256: "Tidak ada paksaan untuk (menganut) agama (Islam); sesungguhnya telah jelas jalan yang benar dengan jalan yang sesat”.

Selain itu, ada pula ayat Al-Qur'an yang menekankan saling menghargai perbedaan kultural. Mengenai pengakuan al-Qur'an, tertera dalam surat al-Maidah ayat 69: "Sesungguhnya orang-orang yang beriman, orang-orang Yahudi, Shabi'in, dan orang-orang Nasrani, siapa saja (di antara mereka) yang benar-benar beriman kepada Allah, hari kemudian dan beramal saleh, maka tidak ada kekhawatiran terhadap mereka dan tidak (pula) mereka bersedih hati".

Dalam surat al-Maidah ayat 82: "Sesungguhnya kami dapati orang yang paling keras permusuhannya terhadap orang-orang yang beriman, ialah orang-orang Yahudi dan orang-orang musyrik. Dan sesungguhnya kamu dapati orang yang paling dekat persahabatannya dengan orang-orang yang beriman ialah orangorang yang berkata: "Sesungguhnya kami ini orang Nasrani”, yang demikian itu disebabkan karena di antara mereka terdapat para pendeta dan para rahib, (juga) karena sesungguhnya mereka tidak menyombongkan diri"..

Surat Huud ayat 118-119, dimana Allah menekankan makna perbedaan sebagai sunnatullah. Allah berfirman: "Jika Tuhanmu menghendaki, tentu Dia menjadikan manusia umat yang satu, tetapi mereka senantiasa berselisih pendapat, kecuali orang-orang yang diberi rahmat oleh Tuhanmu. Dan, untuk itulah Allah menciptakan mereka"."Karena mereka berbeda maka Allah menciptakan mereka", kata Muhammad Imarah. ${ }^{13}$

Bukan tempatnya di sini untuk mengeksplorasi ayat-ayat alQu'an terkait Islam toleran. Namun dari sejumlah ayat yang dikutip di atas, itulah yang sering dijadikan dasar dan alasan bahwa Islam adalah agama toleran. Dari situ pula lahir sejumlah penafsiran mutakhir yang mengaitkan Islam dengan pluralisme. Tetapi-

13 Muhammad Imarah, Islam dan Pluralitas: Perbedaan dan Kemajemukan dalam Bingkai Persatuan, terj Abdul Hayyie Al-Katanie (Jakarta: Gema Insani Press, 1999), h. 78. 
sebagaimana pernah disinyalir dengan amat bagus oleh Karlina Supelli dalam orasi ilmiah yang disampaikan dalam acara Nurcholish Madjid Memorial Lecture di Universitas Paramadina pada Agustus 2010_kita sibuk bicara pluralisme tanpa kita sadari di hadapan kita tribalisme politik sektarian, khususnya yang bertumpu di atas agama, justru semakin mengeras. ${ }^{14}$

Lebih lanjut Karlina menulis: Tribalisme politik sektarian menolak argumen apa pun kecuali yang mereka yakini berasal dari tuhan, dan mereka menolaknya dengan cara yang brutal. Mereka menafsirkan realitas (ontologi) secara tunggal, sementara persepsi (epistemologi) diandaikan hanya bergantung pada relasinya dengan realitas yang tunggal itu, dan logika dipandu oleh aksioma pasangan antagonistik A dan non-A. Agamawan beralih menjadi moralis dan pengalaman religius diciutkan ke kode-kode perilaku yang secara dogmatik juga bertumpu ke penafsiran tunggal itu. Inilah saat ketika program-program moral merosot menjadi tirani sosial yang mensahihkan kekerasan untuk menindas apa pun yang dianggap berbeda. ${ }^{15}$

Dari kutipan panjang yang menggugah itu, terbersit rasa pesimis dan apatis bahwa agama (dalam hal ini Islam) sebagai agama toleran. Kalau betul umat Islam Indonesia sangat toleran, mengapa masih sering kita menyaksikan adanya umat Islam yang bersikap fanatis dan ekstremis? Tindakan kekerasan terhadap jamaah Ahmadiyah, pembakaran gereja di sejumlah daerah, pengeboman yang dilakukan para teroris yang beragama Islam, masih sering mewarnai pemberitaan di media nasional dan internasional.

Kita bisa saja menyalahkan pemeluk Islam, bukan agamanya. Tapi kalau ajaran agama Islam itu tak mampu mengubah para pemeluknya untuk sungguh-sungguh bersikap toleran, lalu akan muncul pertanyaan dari orang-orang yang kritis-yaitu orangorang yang banyak berkecimpung di dunia filsafat-bahwa apa

14 Karlina Supelli, "Ciri Antropologis Pengetahuan", dalam Ihsan Ali Fauzi dan Zainal Abidin Bagi (Penyunting), Dari Kosmologi ke Dialog: Mengenal Batas Pengetahuan, Menentang Fanatisme (Bandung: Mizan, 2011), h. 74.

15 Ibid., h. 74-75. 
gunanya agama Islam yang diyakini benar namun tidak mampu mempengaruhi watak pemeluknya?16

Di sini perlu menggali gagasan para pendiri Republik Indonesia ini agar mendapatkan inspirasi dalam mengelola toleransi. Para pendiri republik ini menyadari betul realitas kemajemukan Indonesia, sehingga dasar-dasar bernegara pun menunjukkan semangat merangkul keragaman tanpa meleburnya menjadi keseragaman.

Semboyan republik kita, Bhineka Tunggal Ika, adalah semboyan berkelas dunia dan semboyan yang menunjukkan bahwa Indonesia adalah negara demokratis. Tak banyak negara yang memiliki semboyan sebagus dan seluhur semboyan Indonesia. Ini adalah semboyan yang menampilkan harapan suatu bangsa yang besar untuk menjadi bangsa yang toleran, bangsa yang dihormati dan dihargai bukan oleh karena luasnya wilayah dan banyaknya manusia yang menghuni republik ini. Tetapi, oleh sikap keterbukaan dan toleransi yang dilandasi oleh kejujuran, yang ditunjukkan oleh rakyat Indonesia dalam pergaulan sosial-politik, baik pada arus lokal, nasional, maupun internasional.

Tetapi, dalam kenyataan sehari-hari, bangsa Indonesia sebagai bangsa yang merdeka masih seringkali mempertontonkan kesenjangan antara semboyan dan falsafah negara dengan laku hidup kita sebagai bangsa. Di hari-hari ini begitu mudah rakyat Indonesia marah, padahal dulu orang mengenal Indonesia sebagai bangsa yang pemaaf dan penyabar. Saat ini begitu mudah para remaja kita terpancing untuk berkelahi hanya karena perbedaan kecil yang belum mampu dikelola dengan baik dan arif. Begitu cepat konflik menyulut di negeri ini, lantaran persoalan-persoalan kecil yang tak mampu dikelola dengan baik berdasarkan falsafah Pancasila dan Bhineka Tunggal Ika tersebut, sehingga yang terjadi adalah gelombang kemarahan yang semakin lama semakin mengerikan.

Padahal, sejak kecil orang Indonesia dikenalkan nilai-nilai agama. Bayangkan, hanya di Indonesia pelajaran agama begitu

16 Pertanyaan di atas pernah dilontarkan Nurcholish Madjid dengan mengutip pernyataan A.N. Wilson. Lihat Nurcholish Madjid, Islam Agama Kemanusiaan, (Jakarta: Paramadina, 1995), h. 122. 
sering diajarkan di sekolah. Orang Indonesia telah diajarkan dan dikenalkan tentang agama sejak TK, SD, SLTP, SLTA hingga Perguruan Tinggi. Ribuan ustad dan da'i menyerukan kebajikan di negeri ini dengan landasan ajaran agama. Tapi, kalau betul agama memiliki kontribusi penting bagi perbaikan sikap dan perbuatan pemeluknya, di mana kontibusi itu di hari ini? Karakter manusia Indonesia masih rendah. Sikap tertutup dan intoleran masih menghiasi hari-hari kerja kita. Ekstremisme, radikalisme, terorisme, dan pemaksaan pandangan secara brutal kepada pihak lain, merupakan contoh nyata betapa toleransi di Indonesia masih membutuhkan perjuangan panjang.

Apalagi jika menyimak hasil penelitian yang diprakarsai oleh Martin van Bruinessen beberapa waktu lalu, telah terjadi pergeseran atau pembalikan wajah Islam Indonesia ke arah yang konservatif (conservative turn) dengan indikator yang beragam: mulai dari konflik besar antara Muslim dan Kristen di beberapa daerah, pemboman di Bali dan Jakarta, upaya memasukkan kembali tujuh kata Piagam Jakarta ke amandemen UUD 1945 yang diikuti dengan munculnya perda syariah di beberapa wilayah di Indonesia, kemunculan gerakan-gerakan baru seperti Hizbut Tahrir dan Salafi, serta serangkaian fatwa MUI yang mengharamkan liberalisme, pluralisme, sekulerisme. ${ }^{17}$ Pembalikan dari Islam yang toleran ke arah Islam konservatif-kalau hasil penelitian ini benar adanyamaka ini sungguh mengkhawatirkan. Upaya membangun kerukunan dan toleransi serta dialog antar umat beragama selama puluhan tahun sebelumnya seakan mentah dan tak ada bekasnya.

Penulis sepakat sepenuhnya dengan apa yang pernah dikatakan Abdurrahman Wahid, bahwa orang yang intoleran terlihat ketika ia menyikapi perbedaan. Dalam berbeda pandangan, orang sering memaksakan kehendak dan menganggap pandangan yang dikemukakannya sebagai satu-satunya kebenaran, dan karenanya ingin dipaksakan kepada orang lain. Cara seperti ini menurut Wahid, tidaklah rasional, walau pun kandungan isinya

17 Lihat Martin van Bruinessen (ed), Conservative Turn: Islam Indonesia dalam Ancaman Fundamentalisme, (Bandung: Mizan, 2014). Para peneliti buku ini yaitu Moch Nurichwan, Ahmad Najib Burhani, Mujiburrahman, Muhammad Wildan, Martin van Buinessen. 
sangat rasional. Sebaliknya, pandangan spiritual yang irasional dapat ditawarkan kepada orang lain tanpa paksaan. ${ }^{18}$ Beberapa tahun lalu muncul peristiwa yang cukup mengejutkan ketika ada sebuah buku Pendidikan Agama Islam (PAI) dan Budi Pekerti kelas XI terbitan resmi Kementerian Pendidikan dan Kebudayaan (Kemendikbud) terdapat kalimat begini: "Pembunuhan terhadap orang yang menyembah selain Allah atau musyrik boleh dilakukan".

Kalimat itu jelas memperlihatkan sikap hidup yang keras, fanatis, dan tidak bersahabat, mirip keyakinan para pengikut Khawarij yang membenarkan pembunuhan terhadap mereka yang menyimpang dan tidak sepaham dengan keyakinan mereka. ${ }^{19}$ Sikap semacam ini mengandung permusuhan, kebencian dan menyebarkan watak yang tak bersahabat, mirip keyakinan para teroris. Kata-kata di buku itu mengarahkan pada paham radikal yang bertentangan dengan konstitusi yang menekankan asas toleransi dan penghargaan atas berbagai macam agama, keyakinan, budaya dan golongan. Maka, tak dapat disalahkan jika ada pihak yang menduga bahwa telah terjadi proses infiltrasi paham radikal dalam kalimat di buku tersebut. Padahal dalam beberapa dasawarsa terakhir, bangsa Indonesia sedang menggalakkan kerukunan hidup antar umat beragama, penghargaan atas pluralitas agama, budaya dan etnik serta usaha membangun toleransi yang sungguh-sungguh dalam rangka memasuki pergaulan dunia yang semakin mengglobal.

"Kalau kita tidak ingin menjadi radikal", kata Abdurahman Wahid, "sudah tentu kita harus dapat mengendalikan kecurigaan kita atas proses modernisasi, yang untuk sebagian berakibat kepada munculnya paham 'serba kekerasan', yang saat ini sedang menghinggapi dunia Islam”. ${ }^{20}$ Penulis sepakat sepenuhya apa yang dikatakan Wahid ini, sebab akar munculnya paham-paham garis keras selama ini menyangkut kecurigaan mereka terhadap proses modernisasi yang sekuler serta kecurigaan terhadap Barat.

Di sini pentingnya mengkaji terus-menerus masalah toleransi dan mendialogkannya secara terbuka. Sebab, klaim bahwa

18 Abdurrahman Wahid, Islamku, Islam Anda, Islam Kita, (Jakarta: The Wahid Institute, 2006), h. 67.

${ }^{19}$ Alwi Shihab, Islam Inklusif: Menuju Sikap Terbuka Dalam Beragama (Bandung: Mizan, 1999), h. 285.

20 Ibid., h. 146. 
bangsa Indonesia sebagai bangsa yang toleran kerapkali dipertanyakan dan dikontraskan dengan kenyataan di lapangan dimana masih terdapat umat Islam yang tidak toleran, menyebar kebencian dan bersikap rasis serta menjadi teroris. Dalam skala lokal, masih ada umat Islam yang merusak gereja, menghancurkan masjid milik Ahmadiyah, menyebar isu Negara Islam yang eksklusif.

Tantangan-tantangan semacam itu, jika tidak dikelola dan dicarikan jalan keluar, akan membawa bangsa Indoesia semakin terpuruk di mata dunia sebagai bangsa yang tidak ramah, menyukai kekerasan dan perlakuan tidak adil. Citra Islam akan semakin buruk sehingga dialog toleransi akan sulit dijalankan.

\section{Membangun Toleransi Melalui Jalan Spiritual}

Para ahli dan tokoh agama, baik di tingkat internasional maupun nasional, pada umumnya tak henti-hentinya merespon pertanyaan-pertanyaan kritis di seputar pembalikan wajah Islam yang semakin menunjukkan gejala yang tidak toleran dan tidak ramah tehadap komunitas lain. Mereka mengakui dan percaya bahwa kemajemukan dan keberagaman manusia adalah niscaya dan Islam sama sekali tidak bertentangan dengan masalah kemajemukan. Bahkan, mereka yang optimis menekankan bahwa ajaran Islam dapat menjadi sarana dan jalan untuk menyampaikan dan mensosialisasikan isu-isu terkait kerjasama dan kerukunan umat beragama. Islam dapat menjadi tulang punggung bagi pemberdayaan umat mengenai perbedaan-perbedaan manusia sebagai realitas yang tidak mungkin dinafikan oleh apa pun dan siapa pun. ${ }^{21}$

Dalam konteks kesetaraan berbangsa, kita membutuhkan suatu wawasan toleransi yang mengkedepankan semangat perdamaian dunia. Sebab, seperti pernah dikatakan oleh Hans Kung, suatu tatanan dunia hari ini tidak akan terjadi tanpa hubungan baru antara bangsa-bangsa. Selanjutnya, tak ada tatanan dunia baru bagi negara-bangsa (nation state) tanpa suatu etika dunia yang baru. Kemudian, tak ada kelangsungan hidup manusia tanpa

21 Husein Muhammad, Mengaji Pluralisme Kepada Mahaguru Pencerahan (Bandung: Mizan, 2011), h. 4. 
perdamaian dunia. 22 Oleh karena itu, Islam dapat memberikan kontribusnya bagi etika toleransi melalui pengenalan wawasan kebangsaan kita kepada sebanyak mungkin negara.

Secara internasional, kini cukup banyak aktivis Muslim yang mengenalkan ajaran Islam tentang isu-isu seputar toleransi dan seruan serta ajakan untuk hidup damai di tengah perbedaan. Ambil contoh misalnya dakwah sufistik yang dilakukan Sayyed Hossein Nasr (cendekiwan muslim asal Iran) selama ini di Barat, terutama di Amerika Serikat, dengan mengenalkan wajah Islam yang sejuk, humanis dan mencintai toleransi. Menurut Nasr, hampir seluruh ajaran Islam tentang hal-hal yang bersifat metafisis dan ma'rifah (gnostic) terutama yang terdapat dalam tasawuf dapat memberikan jawaban terhadap berbagai kebutuhan intelektual dewasa ini. Nasr banyak berjasa mengenalkan ajaran tasawuf modern di dunia Barat sebagai solusi sekaligus alternatif bagi isu-isu pluralisme dan multikulturalisme internasional. Nasr sangat yakin jika tasawuf atau dimensi esoterik dalam Islam adalah modal dasar bagi pergaulan antar umat beragama. Kaum sufi adalah mereka yang sangat toleran terhadap ajaran agama-agama lain.

Nasr begitu bersemangat mempromosikan tasawuf di dunia modern Barat, dan sangat gigih membela tasawuf dari serangan dan kritik beberapa kalangan. Baginya, tasawuf dalam Islam tidak dapat dipisahkan dari kesadaran akan Tuhan Yang Maha Esa, Karena dasar utama tasawuf adalah tauhid. ${ }^{23}$ Dunia modern, bagi Nasr, telah lama terjebak dalam kekerasan dan krisis spiritual yang berakibat pada melemahnya dimensi batin untuk menangkal eksesekses negatif yang ditimbulkan dunia modern. Krisis tersebut ditandai dengan semakin banyaknya orang yang mengalami kecemasan, kegelisahan, dan kehampaan batin. Akibat selanjutnya adalah merebaknya penyakit-penyakit spiritual yang berujung pada stres, frustrasi, hingga penurunan martabat manusia serta mengancam eksistensi manusia itu sendiri. Dalam upaya mengatasi krisis tersebut, dapat diatasi melalui upaya mengamalkan kembali

22 Hans Kung, "Perdamaian Dunia, Agama-agama Dunia, Etika Dunia", dalam Ali Noer Zaman (Ed), Agama Untuk Manusia, terj. Ali Noer Zaman (Yogyakarta: Pustaka Pelajar, 2000), h. 243-245.

23 Seyyed Hosein Nasr (ed), Ensiklopedi Tematis Spiritualitas Islam, terj. Rahmani Astuti, (Bandung: Mizan, 2002), h. xix. 
ajaran tasawuf. Tasawuf sudah terbukti mampu menjadi alternatif terhadap kesenjangan antar agama dan krisis modern.

Selain Sayyed Hossein Nasr, ada juga seorang sufi yang amat terkenal yang mendakwahkan Islam sebagai agama perdamaian dan toleran. Sufi tersebut adalah Bawa Muhayyaddin (asal Srilanka). Ia banyak berkeliling ke Amerika Serikat untuk mengenalkan ajaran tasawuf yang toleran, dan beberapa karyanya banyak mendapat pujian dari peneliti Barat. Salah satu bukunya sudah diterjemahkan ke dalam bahasa Indonesia dengan judul Tasawuf Mendamaikan Dunia, yang diberi pengantar oleh Annemarie Schimmel (peneliti tasawuf asal Jerman dan Profesor of Indo-Muslim Culture Harvard University Amerika Serikat). ${ }^{24}$

Secara nasional, kita dapat menggali model-model dakwah yang dikenalkan oleh tokoh-tokoh pembaru Islam seperti Nurcholish Madjid, Abdurrahman Wahid, Jalauddin Rakhmat, Alwi Shihab, dan lainnya. Dengan tanpa sedikit pun mengurangi penghormatan pada jerih payah untuk membangun dialog toleransi, penulis menawarkan jalan keluar yang lain, yang barangkali mengulang apa yang pernah diperbincangkan jauh sebelumnya oleh para ahli dan pengkaji. Penulis menitik-beratkan Islam sebagai ekspresi dari agama cinta dalam rangka menjawab masalah Islam yang tetutup dan Islam garis keras. Haidar Bagir pernah menyebut Islam agama cinta ketika mengantar buku arya John Caputo, Agama Cinta, Agama Masa Depan. Bagir mengatakan, khazanah pemikiran Islam klasik, terutam yang diwakili oleh para kaum sufi, menekankan pentingnya Islam sebagai agama cinta. Bahkan kata asyik-masyuk yang merupakan bentukan dari kata isq (yang berarti cinta) merupakan salah satu istilah kunci dalam tasawuf. Bagir menyebut sufi seperti Ibn Arabi, Ibn al-Faridh dan Rabi'ah al'Adawiyah, kaya akan pengalaman cinta-kasih yang menunjukkan bahwa Islam itu sesungguhnya juga adalah agama cinta. ${ }^{25}$

Tulisan ini, dengan mengangkat "jalan spiritual" sebagai laku Islam yang toleran, berangkat dari suatu usaha menjawab

${ }^{24}$ Bawa Muhayyaddin, Tasawuf Mendamaikan Dunia, terj. Su'aidi Asy'ari (Bandung: Pustaka Hidayah, 2006).

25 Haidar Bagir, "Islam (juga) Agama Cinta: Pengantar Penerbit", dalam John D. Caputo, Agama Cinta, Agama Masa Depan, terj. Martin Lukito Sinaga, (Bandung: Mizan, 2013), h. xi. 
keresahan sebagian kalangan akan wajah Islam yang makin tidak toleran. Penulis menawarkan penggalian kembali akar tasawuf atau jalan mistik Islam sebagai suatu jalan menyongsong Indonesia yang lebih toleran dengan berbagai tantangan yang dihadapinya hari ini dan hari depan. Mengapa penulis menawarkan tasawuf atau jalan spiritual?

Pertanyaan di atas barangkali akan dianggap mengada-ada atau memaksakan kehendak. Tetapi, sebagaimana dikatakan beberapa waktu lalu oleh Syafa'atun Almirzanah di awal karyanya tentang relasi Islam dan Kristen melalui pengenalan jalan mistik, diskursus dan wacana pengalaman spiritual dapat memainkan peranan dalam dialog umat Kristiani-Muslim sebagai bagian dari dialog agama secara umum. ${ }^{26}$ Almirzanah menggali pengalaman mistik dua master besar dunia dari latar belakang agama yang berbeda, yakni Ibn 'Arabi dan Meister Eckhart. Pada bagian akhir artikel ini penulis suguhkan model toleransi yang tulus dari para kaum sufi lain, yang dalam pencarian mereka akan kebenaran, tak segan-segannya menyuguhkan anggur spiritual yang tulus dalam menyikapi perbedaan, termasuk perbedaan agama.

Para sufi besar, seperti al-Hallaj dengan gagasan wabdat alAdyān, Ibn Arabi dengan wahdat al-wujūd, Jalaluddin Rumi dengan puisi esoterik-inklusifnya, adalah mereka yang mampu merajut dan membingkai ajaran Islam yang benar-benar toleran. Dalam sebuah puisinya yang terkenal, Hanya Napas, Jalaluddin Rumi pernah menulis dengan sangat indahnya:

Aku bukanlah seorang kristiani, yahudi, atau muslim, juga bindu budhis, sufi, atau zen. Babkan agama apa pun atau sistem budaya. Aku bukan dari Timur atau Barat, bukan dari lautan atau langit. ${ }^{27}$

Puisi di atas jelas memperlihatkan bagaimana sebaiknya dan semestinya seorang beragama menyikapi agama-agama lain. Itulah inti keterbukaan, inti toleransi yang sejati dari kaum sufi yang arif, yang tak lagi terikat oleh kulit luar agama, melainkan melangkah

26 Syafa'atun Almirzanah, When Mystic Maters Meet: Paradigma Baru dalam Relasi Kristiani-Muslim, (Jakarta: PT. Gramedia Pustaka Utama, 2009), h. xxi.

27 Dikutip dari buku Reshad Field, Tabir Terakhir: Petualangan Rohani ke Negeri Para Darwis, terj. Syarifah Levi (Jakarta: Serambi, 2004), h. 8. 
memasuki alam batin yang penuh penghayatan mendalam. Toleransi para sufi bukan toleransi basa-basi dan sesaat. Jika diperhatikan kalimat-kalimat dalam bait puisi itu sungguh mendalam dan menggugah maknanya. Ia membukakan jalan bagi pertemuan dari hati ke hati, dengan jalan cinta-kasih, dan semangat toleransi tanpa selubung kemunafikan.

Kautsar Azhari Noer pernah menegaskan: "Sejarah telah membuktikan bahwa mistisisme dalam berbagai agama mempunyai tingkat toleransi yang sangat tinggi". ${ }^{28} \mathrm{Hal}$ ini berlaku bagi tasawuf dalam Islam yang memperlihatkan tingkat toleransi yang sungguhsungguh. Bahkan menurut Kautsar Azhari Noer, intelektual muslim Indonesia yang memiliki perhatian luas terhadap tasawuf, di antara berbagai aliran dalam Islam, tasawuf adalah yang paling ramah dan toleran terhadap agama-agama lain. ${ }^{29}$ Pernyataan ini tentu bukan dimaksudkan untuk meyerang aliran lain, tetapi sebentuk afirmasi terhadap jalan spiritual yang membuka ruang seluas-luasnya bagi pergaulan antar umat beragama.

Jalan spiritual adalah jalan yang sepi, bukan jalan basah. Namun ia mampu membukakan jalan dialog dari hati ke hati yang dilandasi oleh sikap cinta kasih dan persaudaraan. Maka, jika demikian adanya, sangat pantas kiranya jika kita berharap banyak terhadap proses membangun perdamaian dunia melalui tasawuf atau jalan spiritual. Sebab, sebagaimana pernah ditegaskan oleh sufi kontemporer asal Srilanka, Bawa Muhayyaddin, tasawuf adalah jalan untuk mendamaikan dunia. ${ }^{30}$ Dengan kata lain, sebuah jalan menuju toleransi sejati.

Dalam kata-katanya Muhammed Arkoun menegaskan jalan tasawuf adalah mutiara penting bagi relasi antar agama. Rujukan Arkoun tentang “jalan tasawuf” sebagai jalan mendekati al-Qur'an dan sejarah pemikiran Islam, berasal dari pemikiran Abul Hasan alAmiri dalam kitabnya, Kitab al-Sa'ädah wal-Is'äd tentang jalan

${ }^{28}$ Kautsar Azhari Noer, "Passing Over": Memperkaya Pengalaman Keagamaan", dalam Komaruddin Hidayat dan Ahmad Gaus AF (ed), Passing Over: Melintasi Batas Agama, (Jakarta: Gramedia, 1998), h. 266.

${ }^{29}$ Ibid., h. 268

${ }^{30}$ Lihat Bawa Muhayyaddin, Tasawuf Mendamaikan Dunia, terj. Su'aidi Asy'ari, diberi kata pengantar oleh Annemarie Schimmel, (Bandung: Pustaka Hidayah, 2006). 
mencapai kebahagiaan. ${ }^{31}$ Melalui kitab al-Amiri tersebut, Arkoun menemukan dua hal mengenai tasawuf. Pertama, tasawuf adalah jalan menuju kebahagiaan. Kedua, tasawuf adalah jalan menuju perdamaian dunia. Untuk yang terakhir ini Arkoun meyakini bahwa dengan beragama secara tasawuf, maka konflik dan permusuhan karena perbedaan agama dapat diperkecil, bahkan dihilangkan. Dari situ kemudian Arkoun banyak menggali "mutiara terpendam dalam pemikiran kaum sufi". Ia menulis tentang jalan hidup yang ditempuh al-Ghazali, sebagai jalan keseimbangan antara lahir dan batin. Sebuah jalan tengah yang menawarkan wajah Islam yang humanis dan toleran. ${ }^{32}$

Di Indonesia, juga berkembang paham-paham spiritual dan kebatinan yang sangat toleran terhadap perbedaan keyakinan. Penulis meyakini jalan dan ekspresi spiritual-sufistik yang kaya di bumi Nusantara ini sangat penting untuk terus digali dan disosialisasikan jika umat Islam di Indonesia dapat menjadi cermin bagi proses toleransi yang sejati. Dengan keragaman ekspresi keagamaan, budaya serta etnik dan bahasa, Indonesia dapat menjadi percontohan bagi keberhasilannya mewujudkan toleransi yang berbasis spiritual.

\section{Penutup}

Indonesia yang kaya akan ekspresi keagamaan dan kebudayaan pernah dianggap sebagai salah satu negara besar yang menjunjung tinggi toleransi. Sikap ini terus dipertahankan hingga hari ini sebagai langkah mengurangi disintegrasi dan konflik karena perbedaan keyakinan. Toleransi menjadi kata ampuh untuk menyikapi adanya perbedaan ekspesi keagamaan, baik dalam konteks perbedaan ekspresi interal agama maupun eksternal agama.

Islam, sebagai agama yang sering disebut sebagai rahmat bagi alam semesta, secara normatif-teologis, bersikap toleran terhadap agama dan kepercayaan lain Akan tetapi, seiring waktu dan perkembangan dunia yang semakin mengglobal, tak jarang

31 Muhammed Arkoun, Membedah Islam di Barat: Menepis Tudingan, Meluruskan Kesalahpahaman, (Jakarta: PT. Gramedia Pustaka Utama, 2004), h. 143.

32 Ibid., h. 226-239. 
muncul upaya pembalikan dan pergeseran penafsiran Islam ke arah yang intoleran, seperti diperlihatkan oleh para penganut Islam garis keras, Islam radikal dan Islam konservatif serta menguatnya kaum salafi di pentas politik Indonesia.

Sebagai bangsa yang multikultural, dan pemeluk Islam terbesar, Indonesia sudah terbukti tak pernah cocok bagi ekspresi keagamaan yang tertutup dan keras. Islam Indonesia kaya akan ekspresi esoterik yang lebih ramah dan terbuka. Inilah dasar bagi bangsa Indonesia yang telah membuktikan dalam perjalanan sejarahnya sebagai bangsa yang lebih cocok dengan ekspresi spiritual yang mendalam, dialog dari hati ke hati yang berlandaskan penghayatan nilai-nilai esoterik, serta toleransi yang dilandasi oleh sikap batin yang inklusif dan saling menghargai. Itulah kekayaan Indonesia yang dapat ditawarkan ke pentas dunia.

Jalan spiritual adalah jalan sepi. Ia membutuhkan kearifan, kebijaksanaan, dan sikap hidup yang damai dan sejuk. Jalan dialog toleransi tak menjadi soal karena para sufi memandang agama sebagai bagian dari penghayatan batin. Namun lebih dari itu, kaum sufi sepanjang sejarahnya di berbagai belahan dunia telah membuktikan pentingnya jalan spiritual bagi Islam yang toleran.

Bahkan, sebagaimana dinyatakan di muka, alian tasawuf dalam Islam adalah aliran yang paling toleran dalam menyikapi kemajemukan keyakinan. Inilah modal sosial-keagamaan yang penting yang dapat dijadian suatu model bagi dialog toleransi yang lebih membumi. Sebab tidak semua negara memiliki modal sosialkeagamaan sebagaimana yang dimiliki oleh bangsa Indonsia. Modal ini dapat dijadikan promosi di tingkat dunia dan lokal untuk menjembatani kesenjangan dan konflik serta dapat digunakan dalam relasi kita dengan komunitas global dan negara-bangsa.

Melalui jalan tasawuf inilah, dengan segala ekspresi esoterik dan artistiknya, dengan segala bentuk ritualnya yang kaya, diharapkan wajah Islam semakin ramah, yang sejuk dan toleran, dapat terwujud dalam perilaku keseharian umat Islam di Indonesia. Sebab, Islam itu toleran, dan mencintai toleransi. [] 


\section{DAFTAR PUSTAKA}

Abdurrahman Wahid, Islamku, Islam Anda, Islam Kita, The Wahid Institute, Jakarta, 2006.

Alwi Shihab, Islam Inklusif: Menuju Sikap Terbuka Dalam Beragama, Mizan, Bandung, 1999.

Bawa Muhayyaddin, Tasawuf Mendamaikan Dunia, terj. Su'aidi Asy'ari, diberi kata pengantar oleh Annemarie Schimmel, Pustaka Hidayah, Bandung, 2006.

Budhy Munawar-Rachman, Sekularisme, Liberalisme dan Pluralisme, Grasindo, Jakarta, 2010.

Haidar Bagir, "Islam (juga) Agama Cinta: Pengantar Penerbit", dalam John D. Caputo, Agama Cinta, Agama Masa Depan, terj. Martin Lukito Sinaga, Mizan, Bandung, 2013.

Hans Kung, "Perdamaian Dunia, Agama-agama Dunia, Etika Dunia", dalam Ali Noer Zaman (Ed), Agama Untuk Manusia, terj. Ali Noer Zaman, Pustaka Pelajar, Yogyakarta, 2000.

Husein Muhammad, Mengaji Pluralisme Kepada Mahaguru Pencerahan, Mizan, Bandung, 2011.

JB. Banawiratma dan Zainal Abidin Bagir (ed), Dialog Antar umat Beragama: Gagasan dan Pralktik di Indonesia, Mizan, Bandung, 2010.

John L. Esposito, Masa Depan Islam: Antara Tantangan Kemajemukan dan Benturan dengan Barat, terj. Yuliani Liputo, Mizan, bandung, 2010.

Karlina Supelli, "Ciri Antropologis Pengetahuan", dalam Ihsan Ali Fauzi dan Zainal Abidin Bagi (Penyunting), Dari Kosmologi ke Dialog: Mengenal Batas Pengetahuan, Menentang Fanatisme, Mizan, Bandung, 2011.

Kautsar Azhari Noer, "Passing Over": Memperkaya Pengalaman Keagamaan", dalam Komaruddin Hidayat dan Ahmad Gaus AF (ed), Passing Over: Melintasi Batas Agama, Gramedia, Jakarta, 1998.

Martin van Bruinessen (ed), Conservative Turn: Islam Indonesia dalam Ancaman Fundamentalisme, Mizan, Bandung, 2014. Para peneliti buku ini yaitu Moch Nurichwan, Ahmad Najib Burhani, Mujiburrahman, Muhammad Wildan, Martin van Bruinessen. 
Muhammad Imarah, Islam dan Pluralitas: Perbedaan dan Kemajemukan dalam Bingkai Persatuan , terj Abdul Hayyie Al-Katanie, Gema Insani Press, Jakarta, 1999.

Muhammed Arkoun, Membedah Islam di Barat: Menepis Tudingan, Meluruskan Kesalahpahaman, PT. Gramedia Pustaka Utama, Jakarta, 2004.

Nurcholish Madjid, Islam Agama Kemanusiaan, Paramadina, Jakarta,1995.

Nur Syam, Tantangan Multikulturalisme Indonesia: Dari Radikalisme Menuju Kebangsaan, Kanisius, Yogyakarta, 2009.

Reshad Field, Tabir Terakhir: Petualangan Rohani ke Negeri Para Darwis, terj. Syarifah Levi, Serambi, Jakarta, 2004.

Seyyed Hosein Nasr (ed), Ensiklopedi Tematis Spiritualitas Islam, terj. Rahmani Astuti, Mizan, Bandung, 2002.

Syafa'atun Almirzanah, When Mystic Maters Meet: Paradigma Baru dalam Relasi Kristiani-Muslim, PT. Gramedia Pustaka Utama, Jakarta, 2009. 